\title{
Bioactive Amines in Brazilian Wines: Types, Levels and Correlation with Physico-Chemical Parameters
}

\author{
Solange C. Souza ${ }^{1}$, Karine H. Theodoro ${ }^{1}$, Élson R. Souza ${ }^{2}$, Silvana da Motta ${ }^{1}$ and Maria Beatriz \\ Abreu Glória ${ }^{1^{*}}$ \\ ${ }^{1}$ Departamento de Alimentos; Faculdade de Farmácia; Universidade Federal de Minas Gerais; R. Zilah Correa \\ Araújo 416; 31310-450; beatriz@farmacia.ufmg.br; Belo Horizonte - MG - Brazil. ${ }^{2}$ Laboratório de Análise de \\ Bebidas; Ministério da Agricultura e do Abastecimento; Andradas - MG - Brazil
}

\begin{abstract}
The levels of ten bioactive amines and the physico-chemical characteristics of Cabernet Sauvignon, Cabernet Franc and Merlot wines from Bento Gonçalves, RS, Brazil, vintage of 1999 were investigated. The physico-chemical characteristics varied significantly: $\mathrm{pH}$ from 3.80 to 4.07, total acidity from 67.7 to $85.3 \mathrm{meq} / \mathrm{L}$, alcohol content from 11.45 to $12.46 \mathrm{~mL} / 100 \mathrm{~mL}$ and total $\mathrm{SO}_{2}$ from 9.6 to $102 \mathrm{mg} / \mathrm{L}$. Six amines were detected in every sample spermidine, putrescine, histamine, tyramine, serotonine and phenylethylamine. Total amine levels ranged from 2.03 to $7.60 \mathrm{mg} / \mathrm{L}$. Putrescine was the prevalent amine, contributing with 20 to $66 \%$ of total levels. The amine profile and total levels were affected to a greater extent by vinification practices compared to grape type. There was significant correlation between some amines and also between amines and the physico-chemical parameters. Histamine levels were well below limits recommended by several countries.
\end{abstract}

Key words: Red wine; amines; histamine; tyramine

\section{INTRODUCTION}

Bioactive or biologically active amines are low molecular weight organic bases, formed by biochemical processes and are involved in metabolic and physiologic functions in every living organism, playing several important roles (Halász et al., 1994; Lima and Glória, 1999). Spermine, spermidine and putrescine are involved in DNA, RNA and protein synthesis, growth, membrane stabilization and senescence prevention. Histamine and serotonine are vaso- and neuroactive and can also protect plants from insect and predators (Smith, 1985). However, at high concentrations, some amines can cause undesirable physiological effects in sensitive humans. For example, histamine is the causative agent of physiological distresses experienced by some individuals following wine ingestion. The symptoms commonly reported include intense headache, low blood pressure, heart palpitation, edema, rashes, facial flushing, thirst, sore throat, itching, swelling, nausea, diarrhea, and vomiting. Tyramine, tryptamine and 2-phenylethylamine can increase blood pressure, and cause migraines. Toxic levels reported for some amines in foods in general are $10 \mathrm{mg} / 100 \mathrm{~g}$ for histamine and tyramine, and $0.3 \mathrm{mg} / 100 \mathrm{~g}$ for phenylethylamine. The toxic effects of these amines are potentiated in the presence of alcohol, acetaldehyde and other amines (Taylor, 1985; Radler and Fäth, 1991; Lehtonen, 1996; Soufleros et al., 1998). According to Battaglia and Frolich (1978),

\footnotetext{
Author for correspondence
} 
concentrations of $5 \mathrm{mg} / \mathrm{L}$ of histamine may provoke headache after the consumption of $0.5 \mathrm{~L}$ of wine.

Some amines are normal constituents of grapes with amounts varying with variety, soil type and composition, fertilization and climatic conditions during growth and degree of maturation. Putrescine and spermidine are usually abundant in grapes, whereas agmatine, cadaverine, spermine, histamine, tyramine and phenylethylamine have been found in small amounts (Ough, 1971; Zee et al., 1983; Vidal-Carou et al., 1990; Glória et al., 1998; Hajós et al., 2000; Sass-Kiss et al., 2000).

Besides the amines already present in grapes, several can be formed and accumulate during wine making. However, reports in this regard are contradictory. According to Vidal-Carou et al. (1990), there was a slight formation of tyramine and no histamine formation during alcoholic fermentation of Spanish wines. Buteau et al. (1984) found histamine production during alcoholic fermentation. However, in these studies there was no control of the microbial population present in the must, therefore, the formation of amines could not be attributed solely to yeasts. Most researchers attribute the formation of amines, especially tyramine and histamine, to the action of bacteria involved in malolactic fermentation (Buteau et al., 1984; Vidal-Carou et al., 1990; Soufleros et al., 1998). The rates of formation and the levels of amines accumulated in wines vary widely according to the type of microorganisms involved. However, according to Vidal-Carou et al. (1990), malolatic fermentation did not necessarily result in the formation of biogenic amines.

Evidences of amine formation during malolactic fermentation have been described in the literature. According to Soufleros et al. (1998), during fermentation carried out by indigenous lactic acid bacteria, amino acid concentrations decreased significantly while bioactive amines increased. Delfini (1989) compared the ability of several strains of Leuconostoc spp., Lactobacillus spp., and Pediococcus spp. to produce histamine, and observed that Pediococcus damnosus (P. cerevisiae) had the capability to produce significant amounts while Leuconostoc oenos $(O$. oeni) strains were poor producers. LafonLafoucade (1975) suggested that histamine build up occurred mainly as a result of bacteria growth in poor media. Lounvaud-Funel and Joyeux (1994) showed that histamine production by $O$. oeni was stimulated in media without glucose or malic acid and depended particularly on the histidine concentration of the media. Under these conditions, histidine decarboxylation contributed to an additional energy source for the bacteria as already demonstrated for other microorganims (Molenaar et al., 1993). Moreno-Arribas et al. (2000) isolated Lactobacillus brevis and $L$. hilgardii capable of tyramine and phenylethylamine formation from wines containing high amines levels. They observed that the factors affecting tyramine formation were tyrosine levels in the must and also the presence of sugars, mainly glucose.

There are reports indicating the possibility that amines are formed in wine by the action of contaminant microorganisms or by those not directly implicated in the fermentation process, for example enteric bacteria (Buteau et al., 1984). In this case, formation of amines was related to the lack of hygiene during wine-making. Based on this assumption, histamine alone or together with other amines could be an indicator of the quality of raw materials employed or unsanitary conditions prevailing during wine production (Buteau et al., 1984; Vidal-Carou et al., 1990; Soufleros et al., 1998).

Besides the presence of microorganisms, the influence of other factors during the vinification process has also been cited, which include must treatment, length of fermentation in the presence of pulp and skin, alcohol content, sulfur dioxide concentration, added nutrients, $\mathrm{pH}$, temperature and quantity and type of finings and clarification agents (Zee et al., 1983; Buteau et al., 1984; Somavilla et al., 1986; Glória et al., 1998; Vazquez-Lasa et al., 1998; Lima and Glória, 1999; Hajós et al., 2000; Sass-Kiss et al., 2000; Leitão et al., 2000; Arena and Manca de Nadra, 2001).

The study of amines in wines is of interest for two reasons: the toxicological risk from the ingestion of elevated amounts of these substances and the possibility that there is a relationship between high amine content and the quality of the grape used in the production of the wine and also the hygienicsanitary conditions prevalent during processing (Vidal-Carou et al., 1990). Battaglia and Frolich (1978) pointed out that routine checking of the biogenic amines content of wines was of interest as a method of detecting the possibility of defective production procedures.

The content of bioactive amines in wines may be regulated in the future by implementing the FDA regulations as happened with fish (Glória et al., 1998). Some countries have established limits for 
histamine in wines. Switzerland recommends 10 $\mathrm{mg} / \mathrm{L}$ as maximum level, Germany - $2 \mathrm{mg} / \mathrm{L}$, Belgium - $5 \mathrm{mg} / \mathrm{L}$ and France - $8 \mathrm{mg} / \mathrm{L}$ (Lehtonen, 1996; Lima and Glória, 1999). No limits have been suggested for the presence of these amines in Brazilian wine. Furthermore, no information is available on the levels of amines in Brazilian wines. The objective of this work was to investigate the profile and levels of bioactive amines in Cabernet Sauvignon, Carbernet Franc and Merlot wines, from the 1999 vintage from the region of Bento Gonçalves, RS, Brazil. The specific objetives were to: (i) determine the profile and levels of bioative amines; (ii) determine the physico-chemical characteristics; and (iii) correlate amine levels with physico-chemical characteristics of the wines.

\section{MATERIALS AND METHODS}

\section{Samples}

Samples of four different brands of Cabernet Sauvignon wines and of three different brands of Cabernet Franc and Merlot from the region of Bento Gonçalves, Rio Grande do Sul from the 1999 vintage, were purchased at retail stores in Belo Horizonte, MG, Brasil. Overall 30 samples were purchased, three samples of each brand.

\section{Reagents}

Bioactive amine standards were purchased from Sigma Chemical Co. (St. Louis, MO, EUA). They included putrescine (PUT) dihydrochloride, spermidine (SPD) trihydrochloride, spermine (SPM) tetrahydrochloride, agmatine (AGM) sulfate, cadaverine (CAD) dihydrochloride, serotonine (SRT) hydrochloride, histamine (HIM) dihydrochloride, tyramine (TYM), tryptamine (TRM) and 2-phenylethylamine (PHM) dihydrochloride.

Most reagents were of analytical grade, except HPLC reagents, which were LC grade. Ultrapure water was obtained from Milli-Q. The mobile phases were filtered in HAWP and HVWP membranes, used respectively for aqueous and organic solvents $(47 \mathrm{~mm}$ diameter and $0.45 \mu \mathrm{m}$ pore size, Millipore Corp., Milford, MA, USA).

\section{Determination of bioactive amines}

The wine samples were homogenized, degassed in an ultrasonicator, centrifuged at $10000 \times \mathrm{g}$ at $4{ }^{\circ} \mathrm{C}$ for 20 minutes, and filtered through HAWP membrane. The amines were separated by ionpair reverse phase HPLC and quantified fluorimetrically after post-column derivatization with $o$-phthalaldehyde (Vale and Glória, 1997). Liquid chromatography was performed on a LC10AD system connected to a RF-551 spectrofluorimetric detector at 340 and $445 \mathrm{~nm}$ of excitation and emission, respectively, and to a CBM-10AD controller (Shimadzu, Kyoto, Japan). A reversed-phase $\mu$ Bondapak $\mathrm{C} 18$ column, $300 \mathrm{x}$ $3.9 \mathrm{~mm}$ i.d., $10 \mu \mathrm{m}$, was used with a $\mu$ Bondapak C18 guard-pak insert (Waters, Milford, MA). The mobile phases were: A, solution of $0.2 \mathrm{M}$ sodium acetate and $10 \mathrm{~m} M$ 1-octanesulfonic acid sodium salt adjusted to $\mathrm{pH} 5.0$ with acetic acid; and $\mathrm{B}$, acetonitrile. The flow rate was set at $0.8 \mathrm{~mL} / \mathrm{min}$ and the gradient was: $13 \mathrm{~min}$ at $11 \% \mathrm{~B}, 19 \mathrm{~min}$ at $30 \% \mathrm{~B}, 24 \mathrm{~min}$ at $11 \% \mathrm{~B}$, and $45 \mathrm{~min}$ at $11 \% \mathrm{~B}$. The post-column derivatization reagent was delivered at $0.4 \mathrm{~mL} / \mathrm{min}$. It consisted of $1.5 \mathrm{~mL}$ Brij-35, $1.5 \mathrm{~mL}$ mercaptoethanol and $0.2 \mathrm{~g} o$ phthalaldehyde dissolved in $500 \mathrm{~mL}$ solution of 25 $\mathrm{g}$ boric acid and $22 \mathrm{~g} \mathrm{KOH}$ ( $\mathrm{pH}$ adjusted to 10.5 with $3 \% \mathrm{KOH})$. The column and the post-column reaction apparatus were at room temperature $(22 \pm$ $\left.1{ }^{\circ} \mathrm{C}\right)$. The identification of amines was performed by comparison of retention time of amines in samples to standard solutions and also by addition of the suspected amine to the sample. Amine levels were calculated by direct interpolation in the standard curve.

\section{Determination of physico-chemical parameters} The $\mathrm{pH}$, total and volatile titratable acidity, alcohol content and total sulfur dioxide were determined (Brasil, 1986).

\section{Statistical analysis}

The results were submitted to analysis of variance and the means were compared by the Duncan test at $5 \%$ probability. Sperman correlation at 1 and $5 \%$ probability was used to determine relationships between amines and physico-chemical parameters (Sampaio, 1998).

\section{RESULTS AND DISCUSSION}

\section{Types of bioactive amines in the wines}

Among the ten amines investigated, only six were detected in the samples analyzed. Spermidine, putrescine, histamine, tyramine, serotonine and 
phenylethylamine were found in every sample analyzed, except for histamine in one brand of Cabernet Franc. All of these amines have been detected in wines previously (Radler and Fäth, 1991; Lehtonen, 1996; Glória et al., 1998).

Spermine and agmatine were found in trace amounts, below detection limit $(\leq 0.01 \mathrm{mg} / \mathrm{L})$ in three samples. Tryptamine and cadaverine were not detected in any sample (detection limit $\leq 0.01$ $\mathrm{mg} / \mathrm{L}$ ). Tryptamine was also not detected by Glória et al. (1998) in Cabernet Sauvignon and by Zee et al. (1983) in red wines from different countries. The presence of cadaverine was also not detected in Villard Noir wine (Buteau et al., 1984). However, it was found in Rioja (Vazquez-
Lasa et al., 1998), French (Soufleros et al., 1998) and Hungarian (Sass-Kiss et al., 2000) wines. Furthermore, it was the second most prevalent in Oregon (Glória et al., 1998) and New York (Baucom et al., 1986) wines.

Spermidine and putrescine have been detected in grapes. According to Broquedis et al. (1989), these amines are found in the pericarp of Cabernet Sauvignon berries. However, putrescine can also be produced by lactic acid bacteria (Lactobacillus hilgardii and Lactococcus plantarum) from the degradation of the amino acid arginine or the amino acid derived ornithine (Arena and Manca de Nadra, 2001).

Table 1 - Types and levels of bioactive amines in different brands (A - E) of Brazilian Cabernet Sauvignon, Cabernet Franc and Merlot wines from the region of Bento Gonçalves, RS from the 1999 vintage

\begin{tabular}{|c|c|c|c|c|c|}
\hline \multirow[t]{2}{*}{ Amines } & \multicolumn{5}{|c|}{ Amines levels in different brands of wines* $(\mathrm{mg} / \mathrm{L})$} \\
\hline & $\mathbf{A}$ & B & C & D & $\mathbf{E}$ \\
\hline \multicolumn{6}{|c|}{ Cabernet Sauvignon } \\
\hline SPD & - & $0.37 \pm 0.15^{\mathrm{b}}$ & $0.20 \pm 0.00^{\mathrm{b}}$ & $0.10 \pm 0.00^{c}$ & $1.63 \pm 0.12^{\mathrm{a}}$ \\
\hline PUT & - & $4.33 \pm 0.15^{\mathrm{a}}$ & $1.43 \pm 0.06^{\mathrm{c}}$ & $2.87 \pm 0.06^{\mathrm{b}}$ & $1.27 \pm 0.81^{\mathrm{c}}$ \\
\hline HIM & - & $0.23 \pm 0.06^{\mathrm{c}}$ & $1.20 \pm 0.00^{\mathrm{a}}$ & $0.50 \pm 0.00^{\mathrm{b}}$ & $1.73 \pm 0.47^{\mathrm{a}}$ \\
\hline TYM & - & $1.07 \pm 0.06^{\mathrm{a}}$ & $1.00 \pm 0.00^{\mathrm{a}}$ & $0.40 \pm 0.00^{\mathrm{c}}$ & $0.83 \pm 0.06^{\mathrm{b}}$ \\
\hline SRT & - & $0.23 \pm 0.06^{\mathrm{b}}$ & $0.60 \pm 0.00^{\mathrm{a}}$ & $0.27 \pm 0.06^{\mathrm{b}}$ & $0.57 \pm 0.15^{\mathrm{a}}$ \\
\hline PHA & - & $1.37 \pm 0.12^{\mathrm{a}}$ & $0.50 \pm 0.00^{\mathrm{b}}$ & $0.20 \pm 0.00^{\mathrm{c}}$ & $1.23 \pm 0.06^{\mathrm{a}}$ \\
\hline Total & - & $7.60 \pm 0.06^{\mathrm{a}}$ & $4.93 \pm 0.06^{\mathrm{b}}$ & $4.33 \pm 0.06^{\mathrm{c}}$ & $7.26 \pm 1.20^{\mathrm{a}}$ \\
\hline \multicolumn{6}{|c|}{ Cabernet Franc } \\
\hline SPD & $0.10 \pm 0.00^{\mathrm{b}}$ & $0.30 \pm 0.10^{\mathrm{a}}$ & $0.07 \pm 0.06^{\mathrm{c}}$ & - & - \\
\hline PUT & $1.43 \pm 0.12^{\mathrm{a}}$ & $0.77 \pm 0.06^{\mathrm{c}}$ & $1.13 \pm 0.12^{\mathrm{b}}$ & - & - \\
\hline HIM & $0.10 \pm 0.00^{\mathrm{b}}$ & $0.00 \pm 0.00^{\mathrm{c}}$ & $1.37 \pm 0.15^{\mathrm{a}}$ & - & - \\
\hline TYM & $0.30 \pm 0.00^{\mathrm{b}}$ & $0.33 \pm 0.06^{\mathrm{b}}$ & $0.83 \pm 0.00^{\mathrm{a}}$ & - & - \\
\hline SRT & $0.20 \pm 0.00^{\mathrm{b}}$ & $0.50 \pm 0.10^{\mathrm{a}}$ & $0.50 \pm 0.10^{\mathrm{a}}$ & - & - \\
\hline PHA & $0.50 \pm 0.00^{\mathrm{a}}$ & $0.17 \pm 0.06^{\mathrm{c}}$ & $0.37 \pm 0.06^{\mathrm{b}}$ & - & - \\
\hline Total & $2.63 \pm 0.12^{\mathrm{b}}$ & $2.07 \pm 0.17^{\mathrm{c}}$ & $4.27 \pm 0.49^{\mathrm{a}}$ & - & - \\
\hline \multicolumn{6}{|l|}{ Merlot } \\
\hline SPD & $0.03 \pm 0.06^{c}$ & $0.10 \pm 0.00^{b}$ & $0.23 \pm 0.06^{\mathrm{a}}$ & - & - \\
\hline PUT & $1.00 \pm 0.10^{\mathrm{a}}$ & $1.10 \pm 0.00^{\mathrm{a}}$ & $0.97 \pm 0.06^{\mathrm{a}}$ & - & - \\
\hline HIM & $0.07 \pm 0.06^{\mathrm{b}}$ & $0.10 \pm 0.00^{\mathrm{b}}$ & $1.67 \pm 0.06^{\mathrm{a}}$ & _ & _ \\
\hline TYM & $0.33 \pm 0.06^{\mathrm{b}}$ & $0.50 \pm 0.00^{\mathrm{a}}$ & $0.50 \pm 0.00^{\mathrm{a}}$ & - & - \\
\hline SRT & $0.20 \pm 0.00^{\mathrm{b}}$ & $0.50 \pm 0.06^{\mathrm{a}}$ & $0.40 \pm 0.00^{\mathrm{a}}$ & - & - \\
\hline PHA & $0.40 \pm 0.00^{\mathrm{b}}$ & $0.20 \pm 0.00^{\mathrm{c}}$ & $1.13 \pm 0.06^{\mathrm{a}}$ & - & - \\
\hline Total & $2.03 \pm 0.12^{\mathrm{c}}$ & $2.60 \pm 0.00^{\mathrm{b}}$ & $4.90 \pm 0.17^{\mathrm{a}}$ & - & - \\
\hline
\end{tabular}

$\mathrm{SPD}=$ spermidine; $\mathrm{PUT}=$ putrescine; $\mathrm{HIM}=$ histamine; TYM $=$ tyramine; $\mathrm{SRT}=$ serotonine; $\mathrm{PHA}=$ phenylethylamine (detection limit $=0.01 \mathrm{mg} / \mathrm{L}$ for the amines, except serotonine $=0.04 \mathrm{mg} / \mathrm{L}$ ). - data not available.

* Mean values with the same letter in the same line do not differ statistically ( $\mathrm{p}<0.05$, Duncan test).

The other amines encountered are usually present in small amounts in grapes (Ough, 1971; Vidal-Carou et al., 1990). However, levels of these amines can increase during wine making, affected by steps 
followed and microorganisms intentionally added (starter cultures) or contaminants (Ough, 1971; Radler and Fäth, 1991; Glória et al., 1998; Hajós et al., 2000; Sass-Kiss et al., 2000).

\section{Total levels of bioactive amines in the wines}

The mean total bioactive amine levels found in the wine samples analyzed are indicated on Table 1. The levels ranged from $2.03 \mathrm{mg} / \mathrm{L}$ in Merlot (brand A) and $2.07 \mathrm{mg} / \mathrm{L}$ in Cabernet Franc (brand B) to 7.60 and $7.26 \mathrm{mg} / \mathrm{L}$ in Cabernet Sauvignon, brands B and E, respectively. Total amine levels varied widely among types of wines included in this study, with higher total levels for Cabernet Sauvignon (4.33 to $7.60 \mathrm{mg} / \mathrm{L}$ ) compared to Cabernet Franc (2.07 - $4.27 \mathrm{mg} / \mathrm{L})$ and Merlot $(2.03-4.90 \mathrm{mg} / \mathrm{L})$. However, for winery C, similar total levels were found in the three types of wine $(4.27$ - $4.93 \mathrm{mg} / \mathrm{L})$.

Comparing different brands of wines of the same type, there was significant difference on total amine levels, except for brands B and E of Cabernet Sauvignon. When comparing samples within the same lot (same type and same winery), there was low variability, with coefficients of variation varying from 0 to $17 \%$.

In Cabernet Sauvignon wines, significantly higher total levels were found in samples from brands B and $\mathrm{E}$; samples from brand $\mathrm{C}$ had intermediate levels and from brand D, the lowest levels. In Cabernet Franc and Merlot wines, higher total amine levels were found in samples from winery $\mathrm{C}$ compared to $\mathrm{A}$ and $\mathrm{B}$. When these results are compared with vinification practices, some observations can be made. Lowest amine levels found in samples from winery A could result from the lack of maturation and aging steps, the use of clarifying agents (gelatin, bentonite) and the fact that no proteolytic enzyme was used. According to the literature, the use of clarifying agents can reduce amine levels (Ough, 1971; Zee et al., 1983). Proteolytic enzymes can also favor amine formation by liberation of amino acids, which are the precursors for bioactive amines. Maturation and aging steps in the production of several fermented foods has been observed to favor amine formation (Lima and Glória, 1999).

Samples from winery C contained intermediate total amine levels. Comparing vinification practices, the differences were the use of proteolytic and cellulosic enzymes and also aging for 6 months. Furthermore, a different clarifying agent agent was used - egg albumin. No information was found on the ability of this agent in reducing amine levels. These factors could explain the differences encountered.

Samples of Cabernet Sauvignon from winery E, had high levels of total amines. There are several factors that could have favored amine formation and accumulation, among them, the use of proteolytic enzymes, length of maturation and aging, and also the fact that no clarifying agent was used. Quality of the grape used and hygienic sanitary conditions during wine making could also have affected total amine levels (Ough, 1971; Radler and Fäth, 1991).

The total amine levels obtained for winery B were low for Cabernet Franc and Merlot, however they were high for Cabernet Sauvignon. Since the same vinification practices were employed, the quality of the grape used and the hygienic sanitary conditions during wine making could have contributed to these results.

Total amine levels detected in the Brazilian wines analyzed were significantly lower than levels reported in the literature, such as, 12.05 to 106.42 $\mathrm{mg} / \mathrm{L}$ for Aszu wines (Hajós et al., 2000; SassKiss et al., 2000); 3.72 to 207.30 and 3.72 to 42.92 $\mathrm{mg} / \mathrm{L}$ for Pinot Noir and Cabernet Sauvignon, respectively (Glória et al., 1998); and 5.69 to 59.42 for Bordeaux wines (Soufleros et al., 1998).

\section{Contribution of individual amine to total levels in the wines}

The contribution of individual amines to total levels is shown in Fig. 1. According to these results, the brand, e.g. the winery, and, therefore, vinification practices and winery hygienic-sanitary conditions, seemed to affect more the profile of amines in the wine compared to the type of wine. In general, putrescine was the amine that contributed the most to total levels, except for wineries $\mathrm{C}$ and $\mathrm{E}$. In these samples, histamine was the prevalent amine. Spermidine was the amine that contributed the least to total levels $(\leq 4.9 \%)$, except for Cabernet Sauvignon - brand E (22.5\%) and for Cabernet Franc - brand B (14.5\%).

The contribution of histamine to total amine levels varied widely (0 to $32 \%$ ). The lowest contribution was observed for samples from wineries A and B.

The reason for these low levels could be related to malolactic fermentation with microorganisms, which had low histidine decarboxylase activity (Delfini, 1989), or to adequate hygienic-sanitary conditions in the wineries (Radler and Fäth, 1991; Vidal-Carou et al., 1989; Soufleros et al., 1998). 

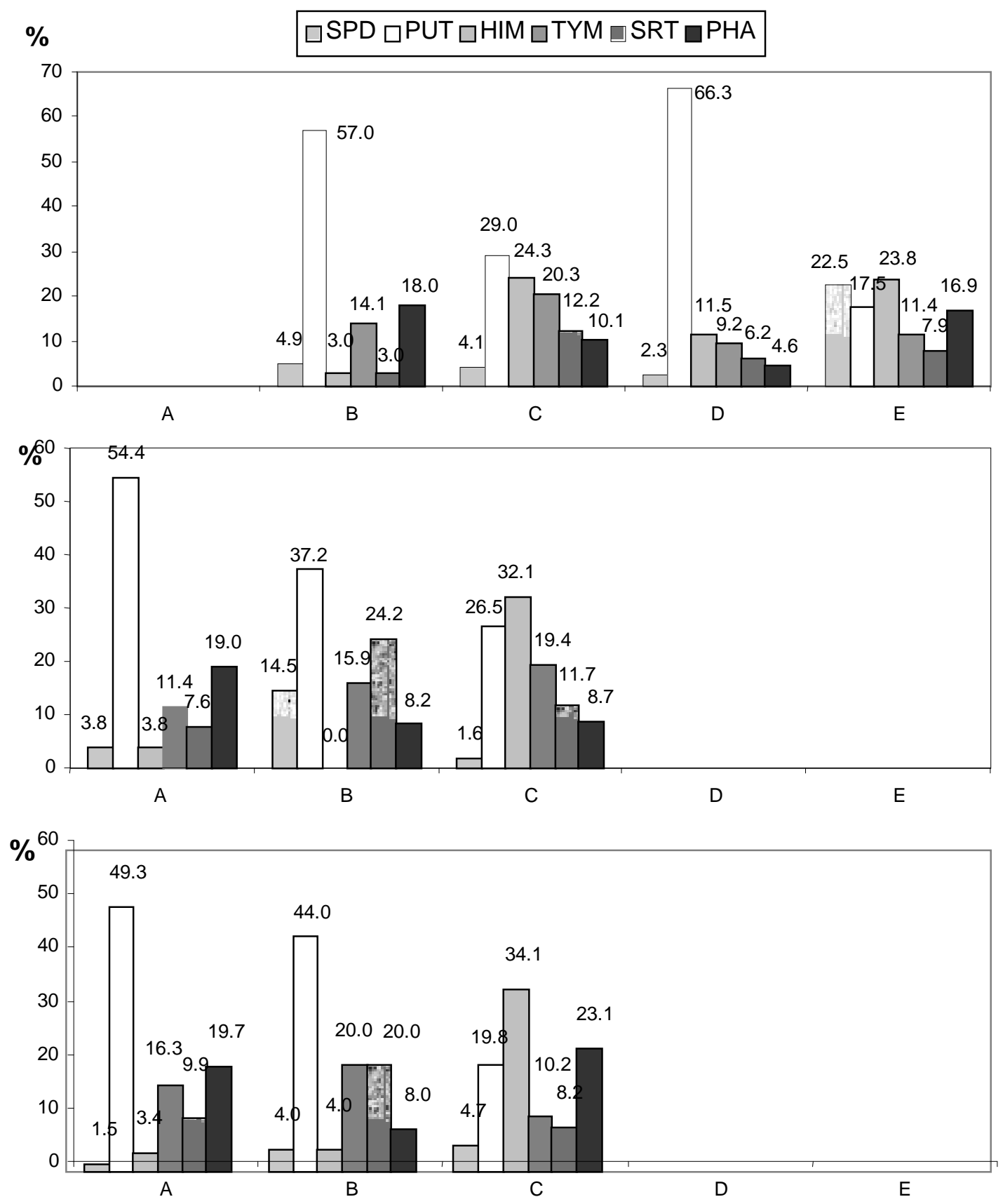

Figure 1 - Contribution of individual amines to the total level in different brands (A - E) of Brazilian Cabernet Sauvignon, Cabernet Franc and Merlot wines from the region of Bento Gonçalves, RS from the 1999 vintage (SPD = spermidine; PUT = putrescine; HIM = histamine; TYM = tyramine; SRT = serotonine; $\mathrm{PHA}=$ phenylethylamine). 
Table 2 - Physico-chemical characteristics of different brands (A - E) of Brazilian Cabernet Sauvignon, Cabernet Franc and Merlot wines from the region of Bento Gonçalves, RS from the 1999 vintage

\begin{tabular}{|c|c|c|c|c|c|}
\hline \multirow[t]{2}{*}{ Parameters } & \multicolumn{5}{|c|}{ Values in different brands of wines } \\
\hline & $\mathbf{A}$ & B & $\mathbf{C}$ & D & $\mathbf{E}$ \\
\hline \multicolumn{6}{|l|}{ Cabernet Sauvignon } \\
\hline $\begin{array}{l}\text { pH } \\
\text { Titratable acidity } \\
\quad(\mathrm{meq} / \mathrm{L})\end{array}$ & - & $3.95 \pm 0.00^{\mathrm{b}}$ & $3.85 \pm 0.00^{\mathrm{c}}$ & $3.80 \pm 0.00^{\mathrm{d}}$ & $4.07 \pm 0.06^{\mathrm{a}}$ \\
\hline $\begin{array}{l}\text { volatile } \\
\text { total }\end{array}$ & $\begin{array}{l}- \\
-\end{array}$ & $\begin{array}{l}10.9 \pm 1.45^{\mathrm{ab}} \\
80.8 \pm 1.75^{\mathrm{b}}\end{array}$ & $\begin{array}{l}8.50 \pm 0.14^{\mathrm{c}} \\
84.0 \pm 0.29^{\mathrm{a}}\end{array}$ & $\begin{array}{l}10.3 \pm 0.29^{\mathrm{b}} \\
81.8 \pm 0.00^{\mathrm{b}}\end{array}$ & $\begin{array}{l}12.00 \pm 0.15^{\mathrm{a}} \\
67.7 \pm 0.00^{\mathrm{c}}\end{array}$ \\
\hline $\begin{array}{l}\text { Alcohol } \\
\qquad\left(\mathrm{mL} / 100 \mathrm{~mL}-20^{\circ} \mathrm{C}\right)\end{array}$ & - & $12.43 \pm 0.18^{\mathrm{a}}$ & $11.90 \pm 0.03^{b}$ & $11.69 \pm 0.13^{b}$ & $12.07 \pm 0.11^{\mathrm{b}}$ \\
\hline Total $\mathbf{S O}_{2}(\mathrm{mg} / \mathrm{L})$ & - & $32.0 \pm 0.0^{\mathrm{b}}$ & $43.0 \pm 6.0^{\mathrm{b}}$ & $51.0 \pm 0.0^{\mathrm{b}}$ & $102 \pm 0.0^{\mathrm{a}}$ \\
\hline \multicolumn{6}{|l|}{ Cabernet Franc } \\
\hline $\begin{array}{l}\mathbf{p H} \\
\text { Titratable acidity } \\
\quad(\mathrm{meq} / \mathrm{L})\end{array}$ & $3.95 \pm 0.00^{\mathrm{a}}$ & $3.90 \pm 0.01^{b}$ & $3.83 \pm 0.03^{c}$ & - & - \\
\hline volatile & $8.58 \pm 0.00^{b}$ & $8.58 \pm 0.00^{b}$ & $10.9 \pm 0.15^{\mathrm{a}}$ & - & - \\
\hline total & $73.7 \pm 0.00^{\mathrm{b}}$ & $83.8 \pm 0.00^{\mathrm{a}}$ & $76.8 \pm 0.00^{\mathrm{b}}$ & - & - \\
\hline $\begin{array}{l}\text { Alcohol } \\
\qquad\left(\mathrm{mL} / 100 \mathrm{~mL}-20^{\circ} \mathrm{C}\right)\end{array}$ & $11.58 \pm 0.09^{c}$ & $12.03 \pm 0.03^{\mathrm{a}}$ & $11.84 \pm 0.03^{\mathrm{b}}$ & - & - \\
\hline Total $\mathbf{S O}_{2}(\mathrm{mg} / \mathrm{L})$ & $30.0 \pm 2.5^{\mathrm{a}}$ & $18.0 \pm 1.2^{\mathrm{b}}$ & $33.0 \pm 1.7^{\mathrm{a}}$ & - & - \\
\hline \multicolumn{6}{|l|}{ Merlot } \\
\hline $\begin{array}{l}\text { pH } \\
\text { Titratable acidity } \\
\quad(\mathrm{meq} / \mathrm{L})\end{array}$ & $3.82 \pm 0.03^{b}$ & $3.88 \pm 0.03^{\mathrm{a}}$ & $3.88 \pm 0.03^{\mathrm{a}}$ & - & - \\
\hline volatile & $8.33 \pm 0.00^{\mathrm{b}}$ & $10.0 \pm 0.15^{\mathrm{a}}$ & $10.4 \pm 0.00^{\mathrm{a}}$ & - & - \\
\hline total & $78.8 \pm 0.00^{\mathrm{b}}$ & $85.3 \pm 0.51^{a}$ & $76.9 \pm 0.29^{c}$ & - & - \\
\hline $\begin{array}{l}\text { Alcohol } \\
\qquad\left(\mathrm{mL} / 100 \mathrm{~mL}-20^{\circ} \mathrm{C}\right)\end{array}$ & $11.45 \pm 0.00^{\mathrm{b}}$ & $12.46 \pm 0.01^{\mathrm{a}}$ & $12.38 \pm 0.10^{\mathrm{a}}$ & - & - \\
\hline Total $\mathbf{S O}_{2}(\mathrm{mg} / \mathrm{L})$ & $9.6 \pm 0.0^{\mathrm{c}}$ & $27.7 \pm 0.5^{\mathrm{b}}$ & $50.0 \pm 1.7^{\mathrm{a}}$ & - & - \\
\hline
\end{tabular}

* Mean values with the same letter in the same line do not differ statistically (p < $0.05 \%$, Duncan test). - data not available.

There are also several steps in the vinification practices from winery A that could render low histamine levels, among them no use of proteolytic enzymes, no maturation or aging step and the use of clarifying agents (Ough, 1971; Vidal-Carou et al., 1990). All of the other amines varied within narrower ranges: tyramine contributed with 9.2 to $20.3 \%$ of total amine levels; serotonine with 3.0 to $24.2 \%$ and phenylethylamine with 4.6 to $23.1 \%$. Tyramine and phenylethylamine have been observed at low levels in grapes (Ough, 1971), however, phenylethylamine levels in Hungarian grapes were very high (Hajós et al., 2000). These amines can also be formed during malolactic fermentation (Moreno-Arribas et al., 2000).
Glória et al. (1998) observed that in Cabernet Sauvignon wines from Oregon, USA, putrescine was the prevalent amine $(63.5 \%)$, followed by histamine $(16.8 \%)$ and spermidine (9.8\%). The prevalence of these amines was also observed for Rioja wines (Vazquez-Lasa et al., 1998); red wines from Tarragona (Busto et al., 1995). However, prevalence of other types of amines has also been reported in the literature, for example, 2phenylethylamine in wines from Hungary (Hajós et al., 2000; Sass-Kiss et al., 2000) and cadaverine in New York wines (Baucom et al., 1986). 
Table 3 - Linear correlation coefficient among bioactive amines and physico-chemical parameters of Brazilian Cabernet Sauvignon, Cabernet Franc and Merlot wines with grapes from the region of Bento Gonçalves, RS from the 1999 vintage

\begin{tabular}{lr}
\hline \multicolumn{1}{c}{ Amines / Parameters } & $\mathbf{R}^{\mathbf{2} *}$ \\
\hline Cabernet Sauvignon & \\
\hline Phenylethylamine x total amines & 0.9958 \\
Spermidine x total acidity & -0.9839 \\
\hline Cabernet Franc & 0.9933 \\
\hline Histamine x Tyramine & 0.9979 \\
Histamine x volatile acidity & 0.9987 \\
Tyramine x volatile acidity & 0.9976 \\
Phenylethylamine x Putrescine & -0.9953 \\
Phenylethylamine x total acidity & -0.9976 \\
Spermidine x total SO $S_{2}$ & -0.9906 \\
\hline Merlot & 1.0000 \\
\hline Histamine x total amines & 1.0000 \\
Tyramine x pH & 0.9975 \\
Putrescine x total acidity & 0.9935 \\
Tyramine x alcohol &
\end{tabular}

\section{Bioactive amine levels in the wines}

There was significant difference (Duncan test, 5\% probability) on the levels of every type of amine detected in the samples from different brands (Table 1). Overall, higher putrescine levels were detected in Cabernet Sauvignon brand B and spermidine levels on Cabernet Sauvignon from brand $\mathrm{E}$. Higher levels of histamine were found in products from wineries $\mathrm{C}$ and $\mathrm{E}$ and higher levels of tyramine in Cabernet Sauvignon from wineries $\mathrm{B}$ and $\mathrm{C}$. Phenylethylamine was detected at higher levels in brands B and E of Cabernet Sauvignon and brand $\mathrm{C}$ from Merlot. Serotonine levels were similar in every sample analyzed.

Overall, amines levels detected in Brazilian wines were lower than or similar to levels reported in the literature. Histamine, tyramine and putrescine levels in Brazilian wines were lower compared to red wines from different countries. Cadaverine, which was only detected in one sample at trace levels, was found at much higher levels and frequency in Cabernet Sauvignon from other countries (Zee et al., 1983; Glória et al., 1998).

The remaining amines were less frequently investigated. Serotonine and 2-phenylethylamine levels were higher, however agmatine levels were lower in Brazilian compared to Oregon wines (Glória et al., 1998).

Health problems associated with wines have been related mainly to high levels of histamine, tyramine and phenylethylamine (Lehtonen, 1996). The samples of wine analyzed had very low levels of these amines and, therefore, would not elicit toxicological effects. Every sample analyzed attended all of the limits established for histamine, including the one from Germany, which is the strictest recommendation $(2 \mathrm{mg} / \mathrm{L})$.

\section{Correlation between amine levels and physico- chemical characteristics}

The results obtained for the physico-chemical characteristics of the wine samples analyzed are indicated on Table 2. Every sample analyzed was in compliance with the limits established by current Brazilian regulations. However, significant difference was observed among brands for every parameter investigated. The $\mathrm{pH}$ values and alcohol contents were similar to those reported by Hertz and Daudt (1992) for Brazilian red wines. However, $\mathrm{pH}$ values found were higher than those observed for Oregon Cabernet Sauvignon wines (Glória et al., 1998).

Results from linear regression $(\mathrm{p}=99.9 \%)$ between bioactive amines and physico-chemical parameters are described on Table 3. Significant correlation between amines was only observed in Cabernet Franc wines for histamine $\mathrm{x}$ tyramine and phenylethylamine $x$ putrescine, indicating that the formation of these amines is affected by the same factors. Total amines levels correlated with 
phenylethylamine in Cabernet Sauvignon wines and with histamine in Merlot wines.

As total acidity increased, there was a significant increase in putrescine levels in Merlot; and a significant decrease in spermidine in Cabernet Sauvignon, and in phenylethylamine in Cabernet Franc. However, as the volatile acidity increased there was a significant increase in histamine and tyramine in Cabernet Franc. Tyramine levels correlated with $\mathrm{pH}$ and with alcohol content in Merlot. Correlation of sulfur dioxide and spermidine was observed for Cabernet Franc and Merlot, however it was negative for the first and positive for the last one.

The negative influence of sulfur dioxide on histamine and tyramine formation was also observed by Vidal-Carou et al. (1990). Significant positive correlation between volatile acidity and histamine and tyramine was observed in the same study. No correlation between alcohol or $\mathrm{pH}$ and amines formation in red wines was observed by Zee et al. (1983). However, Glória et al. (1998) found significant correlation between $\mathrm{pH}$ and alcoholic content and amines levels in Cabernet Sauvignon wines. Furthermore, Vazquez-Lasa et al. (1998) also observed significant correlation of histamine with wine $\mathrm{pH}$. Correlation between volatile acidity and tyramine was also observed by Vidal-Carou et al. (1990). However these authors and others (Rollan et al., Coton and LounvaudFunel, 1995) also found negative correlation of malic and citric acids with histamine levels. Some of the contradictory results were probably due to the small number of samples analyzed.

\section{CONCLUSION}

The levels of ten bioactive amines in Brazilian wines were investigated for the first time. Six different types of bioactive amines were found. The types and levels of biologically active amines in Brazilian Cabernet Sauvignon, Cabernet Franc and Merlot wines were mainly determined by vinification practices adopted by different wineries. Differences encountered could be probably related to several factors, such as use of proteolytic enzymes, length of maturation or aging step, and the use of clarifying agents. Another important factor affecting amine levels could be malolactic fermentation, mainly the type of culture used and the conditions. Furthermore, the quality of raw material, and bacterial contamination in wineries are also important factors, especially during the malolactic fermentation, where efficient control is necessary to avoid amine formation.

The levels of bioactive amines found in Brazilian wines analyzed were very low suggesting that the vinification practices used in the region of Bento Gonçalves, RS, were of high quality. However, some studies following the whole process, including characterization of the grapes should be undertaken to ascertain the influence of specific vinification steps on amine formation. Furthermore, amine could be used to follow up the process and ensure a wine of good quality.

\section{RESUMO}

Os teores de aminas bioativas e as características físico-químicas de Cabernet Sauvignon, Cabernet Franc e Merlot da região de Bento Gonçalves, RS, safra de 1999, foram analisados. As características físico-químicas variaram significativamente: $\mathrm{pH}$ de 3,80 a 4,07; acidez total de 67,7 a 85,3 meq/L, teor alcoólico de 11,45 a 12,46 mL/100 mL e $\mathrm{SO}_{2}$ total de 9,6 a $102 \mathrm{mg} / \mathrm{L}$. Seis aminas estavam presentes em todas as amostras - espermidina, putrescina, histamina, tiramina, serotonina e feniletilamina. Os teores totais de aminas variaram de 2,03 a 7,60 mg/L. Putrescina foi a amina predominante, contribuindo com 20 a $66 \%$ do total. O perfil de aminas foi mais afetado pela vinícola do que pelo tipo de uva. Houve correlação significativa entre aminas e também entre aminas e parâmetros físico-químicos. Os teores de histamina detectados são inferiores aos limites máximos estipulados para o vinho em outros países.

\section{REFERENCES}

Arena, M. E. and Manca de Nadra, M. C. (2001), Biogenic amine production by Lactobacillus. J. Appl. Microbiol., 90, 158-162.

Battaglia, R. and Frolich, D. (1978), HPLC determination of histamine in wine. J. High Resolut. Chromatogr. Commun., 2, 100-101.

Baucom, T. L.; Tabachi, M. H.; Cottrell, T. H. E. and Richmond, B. S. (1986), Biogenic amine content of New York wines. J. Food Sci., 51 : (5), 1376-1377. 
Brasil. Ministério da Agricultura e do Abastecimento (1986), Portaria no. 076 de 27 de novembro de 1986. Metodologia de análise de bebidas e vinagres. Brasília : Secretaria Nacional de Defesa Agropecuária.

Broquedis, M.; Dumery, B. and Boucard, J. (1989), Ise en evidence de polyamines (putrescine, cadaverine, nor-spermidine et spermine) dans les feuilles et les grappes de Vitis vinifer L. Connaiss. Vigne Vin, 23, 1-6.

Busto, O.; Mestres, M.; Guasch, J. and Borrull, F. (1995), Determination of biogenic amines in wine after clean-up by solid-phase extration. Chromatogr., 40 : (7/8), 404-410.

Buteau, C.; Duitschaever, C. L. and Ashton, G. C. (1984), High-performance liquid chromatographic detection and quantitation of amines in must and wine. J. Chromatogr., 284, 201-210.

Delfini, C. (1989), Ability of wine malolactic bacteria to produce histamine. Sci. Aliments, 9, 413-416.

Glória, M. B. A.; Watson, B. T.; Simon-Sarkadi, L. and Daeschel, M. A. (1998), A survey of biogenic amines in Oregon Pinot Noir and Cabernet Sauvignon wines. Am. J. Enol. Vitic., 49, 3 279-282.

Hajós, G.; Sass-Kiss, A.; Szerdahelyi, E. and Bradocsz, S. (2000), Changes in biogenic amine content of Tokaj grapes, wines, and Aszu-wines. J. Food Sci., 65 : (7), 1142-1144.

Halász, A.; Baráth, Á.; Simon-Sarkadi, L. and Holzapfel, W. (1994), Biogenic amines and their production by microorganisms in food. Trends Food Sci. Technol., 5, 42-49.

Hertz, P. F. and Daudt, C. E. (1992), Aspectos químicos e microbiológicos de vinhos do Rio Grande do Sul. Ciência Rural, 22 : (3), 339-343.

Lafon-Lafoucade, S. (1975), L'histamine des vins. Cannaiss. Vigne Vin, 2, 103-115.

Lehtonen, P. (1996), Determination of amines and amino acids in wine: a review. Am. J. Enol. Vitic., 47, 127-133.

Leitão, M. C.; Teixeira, H. C.; Barreto Crespo, M. T. and San Romão, M. V. (2000), Biogenic amines occurrence in wine. Amino acid decarboxylation and proteolytic activities expression by Oenococcus oeni. J. Agric. Food Chem., 48, 2780-2784.

Lima, A. S. and Glória, M. B. A. (1999), Aminas bioativas em alimentos. Bol. SBCTA, 33 : (1), 70-79.

Lounvaud-Funel, A. and Joyeux, A. (1994), Histamine production by wine lactic acid bacteria: isolation of a histamine-producing strain of Leuconostoc oenos. J. Appl. Bacteriol., 77, 401-407.

Molenaar, D.; Bosscher, J. S.; Ten Brink, B.; Drissen, A. J. M. and Konings, W. N. (1993), Generation of a proton motive force by histidine decarboxylation and electrogenic histidine/histamine antiport in Lactobacillus buchneri. J. Bacteriol., 175, 2864-2879.
Moreno-Arribas, V.; Torlois, S.; Joyeux, A.; Bertrand, A. and Lonvaud-Funel, A. (2000), Isolation, properties and behaviour of tyramine-producing lactic acid bacteria from wine. J. Appl. Microbiol., 88, 584-593.

Ough, C. S. (1971), Measurement of histamine in California wines. J. Agric. Food Chem., 19 : (2), 241-244.

Radler, F. and Fäth, K. P. (1991), Histamine and other biogenic amines in wines. In: International Symposium on Nitrogen in Grapes and Wine. Proceeding... Am. Soc. Enol. Vitic. Davis: J. M. Rantz. pp. 185-195.

Rollan, G. C.; Coton, E. and Lounvaud-Funel, A. (1995), Histidine decarboxylase activity of Leuconostoc oenos 9204. Food Microbiol., 12, 455-461.

Sampaio, I. B. M. (1998), Estatística aplicada à experimentação animal. Belo Horizonte : FEPMVZ. $221 \mathrm{pp}$.

Sass-Kiss, A.; Szerdahelyi, E. and Hajós, G. (2000), Study of biologically active amines in grape and wines by HPLC. Chromatographia Suppl., 51, S316-S320.

Smith, T. A. (1985), Polyamines. Ann. Rev. Plant Physiol., 36, 117-143.

Somavilla, C.; Bravo, F.; Inigro, B. and Burdaspal, P. (1986), Histaminogénesis. IV. Accumulation de histamina en medios naturales y semi-sintéticos. Alimentaria, 2, 37-42.

Soufleros, E.; Barrios, M. L. and Bertrand, A. (1998), Correlation between the content of biogenic amines and other wine compounds. Am. J. Enol. Vitic., 49 : (3), 266-278.

Taylor, S. L. (1985), Histamine poisoning associated with fish, cheese and other foods. Monograph. Who, Geneva. 47 pp.

Vale, S. R. and Glória, M. B. A. (1997), Methodology for the determination of biogenic amines in cheese. J. AOAC Int., 80 : (5), 1006-1012.

Vazquez-Lasa, M. B.; Iniguez-Crespo, M.; GonzálezLarraina, M. and González-Guerrero, A. (1998), Biogenic amines in Rioja wines. Am. J. Enol. Vitic., 49 : (3), 229.

Vidal-Carou, M. C.; Izquierdo-Pulido, M. L. and Mariné-Font, A. (1990), Histamine and tyramine in Spanish wines: their formation during the wine making process. Am. J. Enol. Vitic., 41, 160-167.

Zee, J. A.; Simard, R. E. and Heureux, L. (1983), Biogenic amines in wines. Am. J. Enol. Vitic., 34, 6-9.

Received: September 18, 2003; Revised: February 05, 2004; Accepted: September 01, 2004. 